\title{
冷間プレス曲げによる鋼板の材質変化とその改善に関する研究 EXPERIMENT ON THE MECHANICAL PROPERTIES AND THEIR IMPROVEMENT OF COLD PRESS-BENT STEEL PLATES
}

\author{
桑村 仁*, 秋山宏**, 山田. 哲***, 邱榮政**** \\ Hitoshi KUWAMURA, Hiroshi AKIYAMA, Satoshi YAMADA and Jung-Cheng CHIU
}

\begin{abstract}
This research aims at clarifying the effects of cold press-bending on the mechanical properties of steel plates in order to reason the fact that brittle fracture has been witnessed in recent experiments of steel box-columns produced by cold press-forming. The changes in mechanical properties were investigated in the press-bent corner and its welded joint to a diaphragm plate. It was found that the cold press-bending causes the increase in strength, the decrease in ductile elongation capacity, and the remarkable reduction in impact energy absorption in the outer surface. However, these unfavorable mechanical properties related to brittle fracture were completely recovered by postheating of $850^{\circ} \mathrm{C}$-normalizing.
\end{abstract}

Keywords : cold-forming, box-section column, brittle fracture, postheating 冷間成形, 角形鋼管, 脆性破壊, 後熱処理

\section{1. 序}

冷間塑性加工によって鋼材が硬化するとともに強さが 上昇し，逆に延性伸び能力と衝撃値が低下するというこ と，およびこれらの材質変化がひずみ時効によって助長 されるということは古くから知られている2!,3)。建築分 野においてもこれに関する実験が行われており，予ひず みを与えた構造用鋼材について同様の結果が得られてい る(1) 6)。冷間塑性加工によるこれらの材質変化は，建築 で多く用いられている冷間成形角形鋼管の塑性域での部 材性能に対して次の 2 種類の影響を及ぼす。第一は材料 力学的な影響であり, 冷間加工による鋼材の降伏強さの 上昇に起因する部材降伏耐力の増大，および降伏比の上 昇と延性伸び能力の低下に起因する座屈を伴う塑性変形 能力の低下である。第二は破壊力学的な影響であり, 冷 間加工による鋼材の延性伸び能力の低下と切欠き靱性の 低下に起因する高応力脆性破壊を伴う部材塑性変形能力 の急激な培失である。本研究は, 上記のうち後者に関す る基礎的研究を行ったものである。

橋梁分野においては，鋼橋の脆性破壊事故のうちひず
み時効脆化がその原因となっている事故例に基づいて, 冷間加工によって予ひずみを受けた鋼材の使用に対して は厳しい規定が設けられている。例えば，わが国の道路 橋示方書においては, 鋼板の曲げ冷間加工を行う場合は, 内側半径を板厚の 15 倍以上にしなければならないとし ている7。文献 8）によると, SM 50B，SM 41B（旧 呼称）においては衝撃値の規格を下回らないようにする ために予ひずみ量を $3 \%$ 程度以下にする必要があると いう実験結果が得られており，これは上記道路橋示方書 の曲げ半径の制限と合致するとしている。一方, 現行の 冷間成形角形鋼管の規格 ${ }^{9}$ によるとプレス成形コラ゙ムの 場合に内側半径が板厚の 2 - 倍となっており, 単純計 算すればこれは $20 〜 14 \%$ の大きな予ひずみ量になる。

建築分野で泠間加工の規定がこのように緩い理由は, 建築構造物が高サイクル疲労荷重を受けないことや低温 環境で使用されないなどの技術的判断に基づいていると 推測されるが，鋼橋のような脆性破壊事故の経験がまだ 無いこともその一因と考えられる。特に，このような冷 間成形角形鋼管を用いた鋼構造建築が大地震や台風の洗

\footnotetext{
本論文は，参考文献 1）に加筆し，まとめたものである。

* 東京大学工学部建築学科 助教授. Ph. D.

** 東京大学工学部建築学科 教授. 工博

東京大学工学部建築学科 助手. 工修

* 東京大学工学部建築学科 大学院生
}

Assoc. Prof., Dept. of Architecture, Faculty of Engineering, Univ. of Tokyo, Ph. D.

Prof. Dept. of Architecture, Faculty of Engineering, Univ. of Tokyo, Dr. Eng.

Research Assoc., Dept. of Architecture, Faculty of Engineering, Univ. of Tokyo, M. Eng.

Graduate Student, Dept. of Architecture, Faculty of Engineering, Univ. of Tokyo 
礼をまだ受けていないという点については謙虚な認識が 必要であろう。したがって, 冷間成形角形鋼管の終局挙 動が脆性破壊で決まる可能性については，まず実験にお いて調查しなければならないが，この種の実験はあまり 行われておらず，今のところ冷間成形角形鋼管のうち冷 間プレス曲げによって成形されたプレスコラムについて のみ脆性破壊現象が報告されている。特に,このプレス コラムは比較的大形の断面として実用化されているにも かかわらず，そのような部材実験デー夕は試験機容量の 関係で極めて少ないのが現状である ${ }^{10), 11}$ 。

文献 10）によると, 板厚が $19 \mathrm{~mm}$ 以上の比較的大形 のサイズで曲げを受ける梁貫通形式プレスコラムの終局 挙動は, 溶接施工条件にも依存するが, 幅厚比が 18 25 を境に，それより幅厚比が大きい断面では局部座屈 で決まり,それより小さい幅厚比の断面では脆性破壊が 起きるという実験結果が得られている。文献 11) では, 内ダイアフラム形式の板厚 $38 \mathrm{~mm}$, 幅厚比 21 のプレス コラムの角部外側に置かれた溶接ビードの人工切欠きか ら脆性破壊が生じている。これらは，いずれもプレスコ ラムの角部外側における応力集中部に繰返し載荷によっ て生じた延性亀裂が脆性破壊の引き金になっている。終 局挙動が局部座屈から脆性破壊に遷移する上記の遷移幅 厚比は胃在使われているプレスコラムの幅厚比範囲内に あるので，脆性破壊に対する設計上の配虑が必要である ことをこれらの実験結果は示唆している。

また,これらの実験における脆性破壊は, 材料の降伏 応力を超えた繰返し載荷によってかなり塑性変形が生じ た後発生する高応力脆性破壊であり, 大地震に対して塑 性設計を行う建築分野固有の問題といえ, 弾性設計が主 流となっている橋梁や船舶, 圧力容器の分野における低 応力脆性破壊と性質を異にしている。つまり, 塑性ひず み履歴後に発生する高応力脆性破壊は, 低応力脆性破壊 の場合のような残留応力が脆性破壊に影響しているので はなく, 材質そのものの劣化が多軸応力の影響と相まっ て脆性破壊の重要な原因になっていると考えられる。こ れは, 文献11）で1体だけではあるが, 前記の脆性破 壊を起こしたと同し人人工切欠き付きプレスコラムに熱処 理 $\left(620^{\circ} \mathrm{C}, 1.5 \mathrm{hr}\right.$, この熱処理は応力除去焼きなまし であり本来材質改善を目的としたものではないが, 角部 の冷間加工度が高いのでこの程度の温度でも再結晶が進 行し材質はかなり改善される) を施した試験体では脆性 破壊が生じないで局部座屈で終局状態が決定づけられた ことからも支持できる推測と考えられる。また, 文献 12) の実験によると，角部外側に溶接ビードなどの応力集中 源がない場合には脆性破壊が発生していないことから, プレスコラムの脆性破壊にはプレス曲げ角部の外側, つ まり引張予ひずみ側の材質劣化が決定的な影響を与えて いると推定できる。
以上のような背景に基づき, 本研究は, 冷間プレス曲 げによる鋼板の材質変化, さらに熱処理による材質改善 について実験的に調查したものであり，プレス成形角形 鋼管角部の母材および溶接部の基本的な性能を明らかに することを目的としたものである。

\section{2. 実験概要}

\section{1 使用材料}

実験に使用した鋼板はプレス成形コラムの原板として 多く用いられているSM 490 とし，板厚は $25 \mathrm{~mm}$ とし た。この鋼板の機械的性質および化学成分を Table 1 に 示す。

\section{2 試験体製作要領}

冷間プレス曲げによる材質変化, さらに溶接や熱処理 による材質変化を調べるために次の 4 種類の試験体 $\mathrm{A}$, B，C，Dを製作した。

試験体 $\mathrm{A} ：$ 原板 $\rightarrow$ プレス曲げ

試験体 $\mathrm{B}:$ 原板 $\rightarrow$ プレス曲げ $\rightarrow$ 熱処理

Table 1 試験鋼板の機械的性質および化学成分 (SM 490, $\mathrm{t}=$ $25 \mathrm{~mm}$ )

\begin{tabular}{|c|c|c|c|c|c|c|c|c|}
\hline \multicolumn{2}{|c|}{$\begin{array}{l}\text { Mechanical } \\
\text { Properties }\end{array}$} & \multicolumn{7}{|c|}{ Chemical Composition (weight \%) } \\
\hline \begin{tabular}{l|l|}
$\mathrm{YP}^{* 1}$ & $\mathrm{TS}^{* 2}$ \\
\end{tabular} & $\mathrm{EL}^{* 3}$ & $\mathrm{C}$ & $\mathrm{Si}$ & $\mathrm{Mn}$ & $\mathbf{P}$ & s & $\mathrm{C}_{\mathrm{eq}}{ }^{*}$ & $\mathrm{P}_{\mathrm{cm}}^{* 5}$ \\
\hline \begin{tabular}{|l|l|}
3.45 & 5.12 \\
\end{tabular} & 28 & .175 & .46 & 1.43 & .019 & .0056 & .44 & \begin{tabular}{|l|}
.26 \\
\end{tabular} \\
\hline
\end{tabular}

${ }^{\text {"1 }}$ lower yield stress in tonf $/ \mathrm{cm}^{2}$

-2 tensile strength in tonf $/ \mathrm{mm}^{2}$

*3 total elongation in 40-mm gage length in $\%$

${ }^{* 4} \mathrm{C}_{\mathrm{eq}}=\mathrm{C}+\frac{\mathrm{Si}}{24}+\frac{\mathrm{Mn}}{6}+\frac{\mathrm{Ni}}{40}+\frac{\mathrm{Cr}}{5}+\frac{\mathrm{Mo}}{4}+\frac{\mathrm{V}}{14}$
${ }^{* 5} \mathrm{P}_{\mathrm{cm}}=\mathrm{C}+\frac{\mathrm{Si}}{30}+\frac{\mathrm{Mn}}{20}+\frac{\mathrm{Ni}}{60}+\frac{\mathrm{Cr}}{20}+\frac{\mathrm{Mo}}{15}+\frac{\mathrm{V}}{10}+\frac{\mathrm{Cu}}{20}+5 \mathrm{~B}$

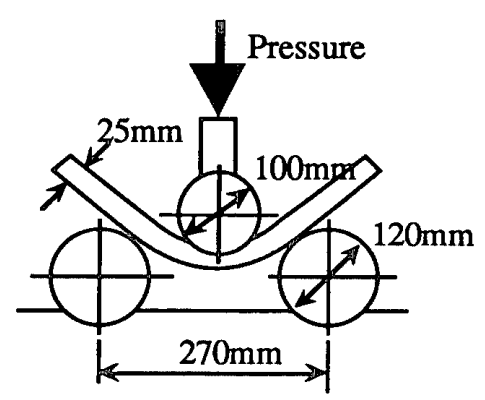

Fig. 1 プレス曲げ試験体の製作方法

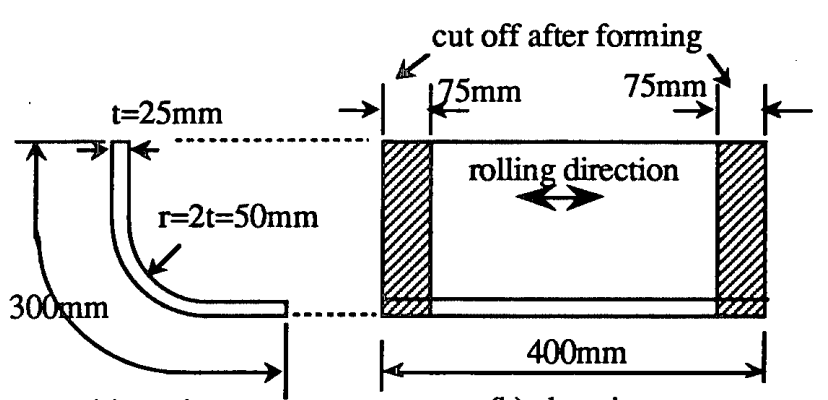

(a) section

(b) elevation

Fig. 2 プレス曲げ試験体の形状寸法 
試験体 $\mathrm{C} ：$ 原板 $\rightarrow$ プレス曲げ $\rightarrow$ 溶接

試験体 D：原板 $\rightarrow$ プレス曲げ $\rightarrow$ 溶接 $\rightarrow$ 熱処理

試験体 $\mathrm{A}$ はプレス曲げのままの試験体であり，試験体 $\mathrm{B}$ はそれに熱処理を施したものである。試験体Cはプレス 曲げのままの試験体に端板を突合せ溶接した試験体であ り，試験体 Dはそれに熱処理を施した試験体である。試 験体 C，Dはプレスコラムの柱梁接合に用いられている 柱貫通ダイアフラム形式の溶接継手を模したものであ る。

プレス曲げは全試験体共通とし，Fig. 1 に示すように 内側半径が板厚の 2 倍となるように 3 点曲げにより常温 で行った。ここで用いた鋼板のサイズはFig. 2 に示す ように幅 $300 \mathrm{~mm}$, 長さ $400 \mathrm{~mm}$ とし, 長手方向を角形 鋼管の管軸とし鋼板の圧延方向と合わせた。

試験体 BとDにおける熱処理は, 通常の応力除去焼き なまし $\left(600 \sim 650^{\circ} \mathrm{C}\right)$ ではなく，材質のほぼ完全な回 復を狙って A 3 変態点温度を超えた $850^{\circ} \mathrm{C}$ まで炉内で昇 温し 30 分保持した後; 炬外で緩やかに空冷したもので あり，焼きならし処理に相当するものである。なお，温 度は試験片に装着した熱電対により制御した。

試験体 CとDにおける溶接は，プレス曲げ試験体の両 端をまず $75 \mathrm{~mm}$ ずつカットした後, Fig. 3 に示すよう に裹当て金を付けてレ形開先で $\mathrm{CO}_{2}$ 半自動溶接により 行った。この時の, 溶接条件は溶接電流 $300 \mathrm{~A}$, アーク 電圧 $35 \mathrm{~V}$, 溶接速度 $15 \mathrm{~cm} / \mathrm{min}$, 入熱量 $40 \mathrm{~kJ} / \mathrm{cm}$ であ り，予熱なし，パス間温度無制限とした。溶接材料は後 述の引張試験において溶接金属での破断をなるべく防ぐ ために 60 キロ用ソリッドワイヤ $(\phi=1.6)$ を用いた。 なお，端板に用いた鋼板はプ.レス曲げ試験体と同じであ る。

\section{3 試験項目と試験片採取}

実施した試験は，小形引張試験, シャルピー衝撃試験, ビッカース硬さ試験, 断面マクロおよびミクロ観察であ る。

これらの試験片の試験体からの採取位置を Fig. 4 に 示す。試験片の数はすべてについて各 1 本のみであるが, 試験結果にはバラッキに起因する不明瞭な点は生じな かった。試験体 A，Bについては，Fig.4-(1) に示すよ うに試験体の端から $75 \mathrm{~mm}$ 離れた位置から，つまりほ ぼ平面ひずみ状態となっている範囲から試験片を採取し た。試験体C，Dについては，Fig.4-(2) に示すように 端板を全部または一部含むように試験片を採取した。こ のとき，開先がレ形になっているためFig.4-(3) に示 すように小形引張試験片の平行部に含まれる溶接金属部 の長さが外側から採取した試験片のほうが内側から採取 した試験片より長くなっている。また，Fig.4-(4) に 示すようにシャルピー衝撃試験片は，ノッチ先端が脆性 破壊の起点となりやすい溶接ボンド付近に一致するよう (a) elevation

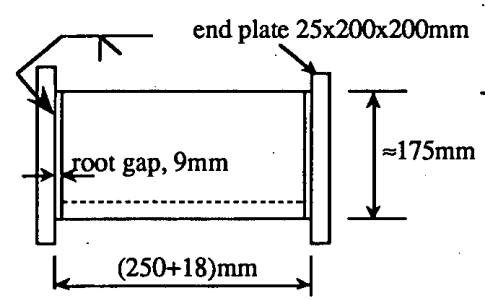

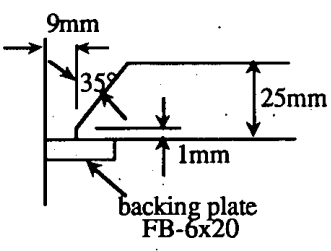

(b) welding detail
Fig. 3 プレス曲げ試験体端部の溶接継手（試験体C，D）

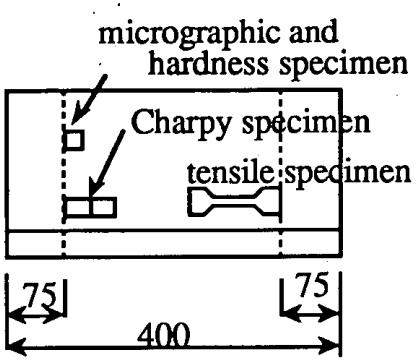

(1) 試験体 A, B
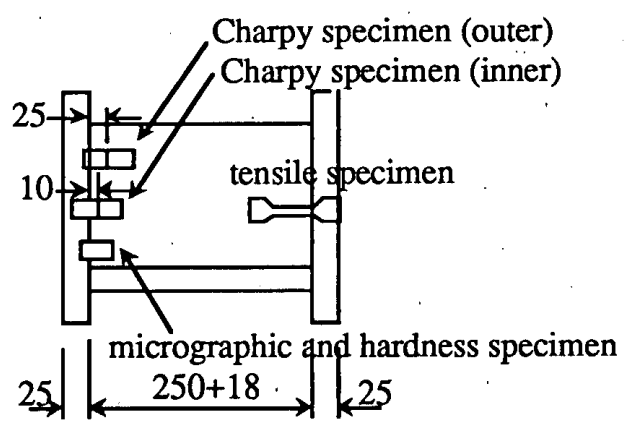

(2) 試験体 C, D

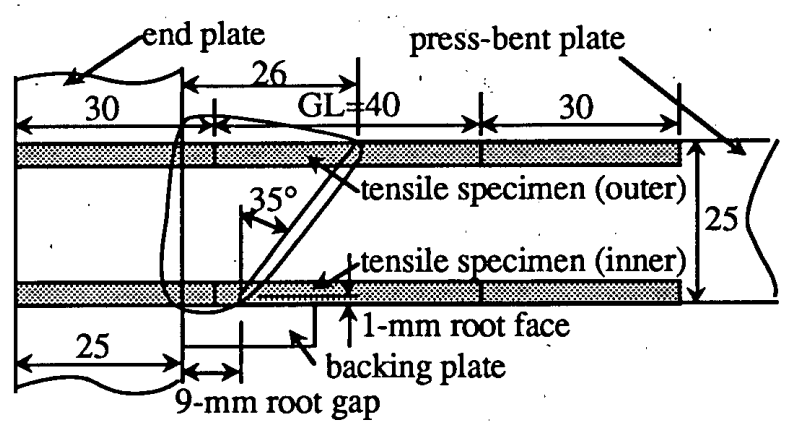

(3) 試験体C, Dにおける小形引張試験片

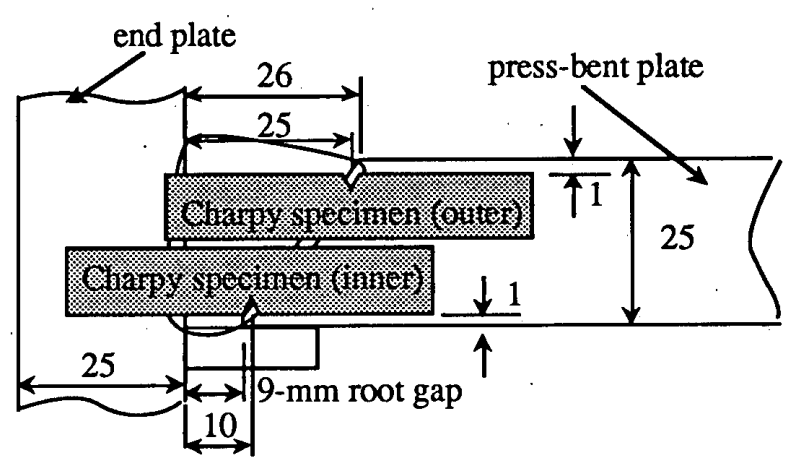

(4) 試験体C, Dにおけるシャルピー衝撃試験片

Fig. 4 各種試験片の採取位置（側面） 


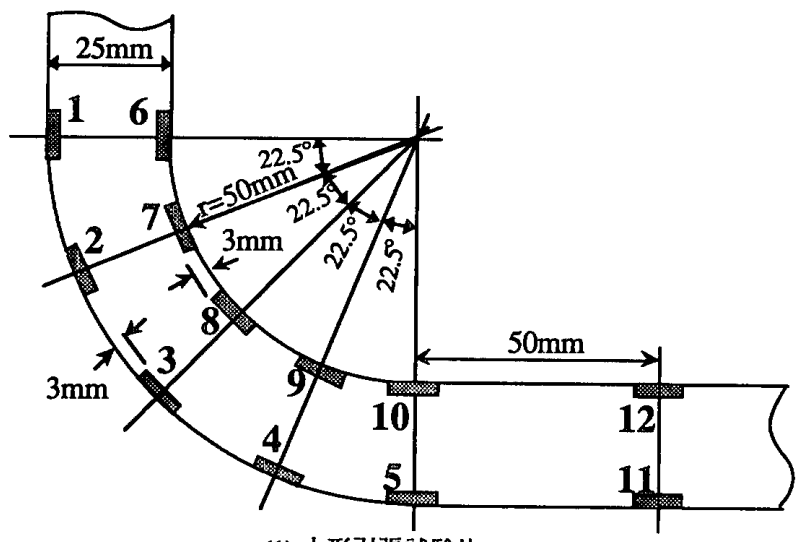

(1) 小形引張試験片

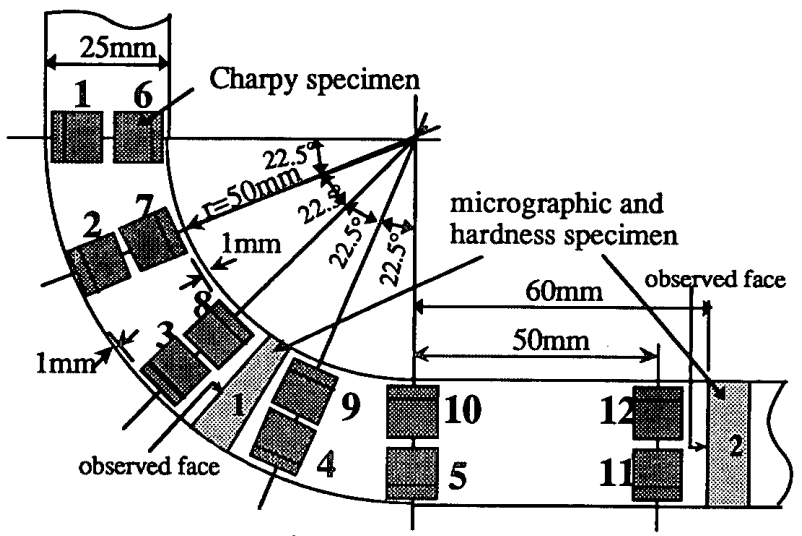

(2) シャルピー沺繁試験片とマクロ試験片

Fig. 5 各種試験片の採取位置（断面）

に配虑したため外側と内側で採取位置がずれている。衝 撃試験における破断面は，外側から採取した試験片では 熱影響部と母材を横断するのに対して, 内側から採取し た試験片では溶接金属を横断することになる。

断面内における試験片の採取位置は，Fig. 5-(1)，(2) に示すように，角部 $90^{\circ}$ を 4 等分した位置と角部終点か ら $50 \mathrm{~mm}$ 離れた平板部とし, 外側（引張予ひずみ側） と内側 (王縮予ひずみ側) から対に採取した。採取位置 を図に示す 1 12 の番号で表す。小形引張試験片および 衝撃試験片の軸線はプレス曲げ試験体の材軸（つまりプ レスコラムの管軸）と平行である。これはプレスコラム の脆性破壊が管軸方向の引張応力によって発生し, 管周 方向に伝播する事実に基づくものである ${ }^{10)}$ 。試験片の名 称は，A3のように試験体記号と採取位置を示す番号の 組み合わせで表記する。なお，断面マクロ試験片は, Fig. 5-(2) に示す角部と平板部から採取し, マクロお よびミクロ観察とともに硬さ試験にも用いた。

脆性破壊の引き金となる延性き裂は局部的な応力集中 部から発生するので，材料の延性に関する情報もできる かぎり断面を細かく分割した位置から取り出したほうが よい。従来のプレスコラム角部の引張試験は全厚試験 ${ }^{12)}$ であるのに対し，ここでの引張試験片は全厚ではなく， プレス曲げ試験体の表面から深さ $3 \mathrm{~mm}$ の範囲で採取し た小形サイズの試験片とした。その形状はFig. 6 に示

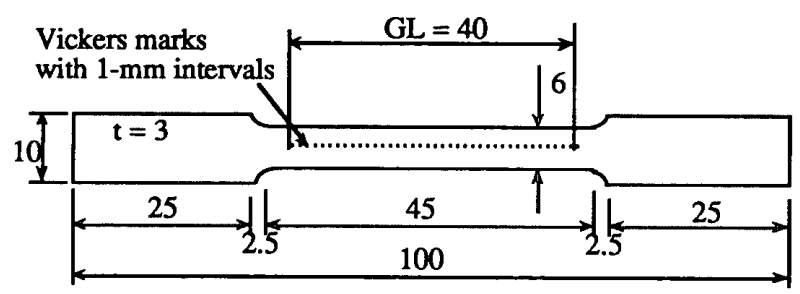

Fig. 6 小形引張試験片の形状

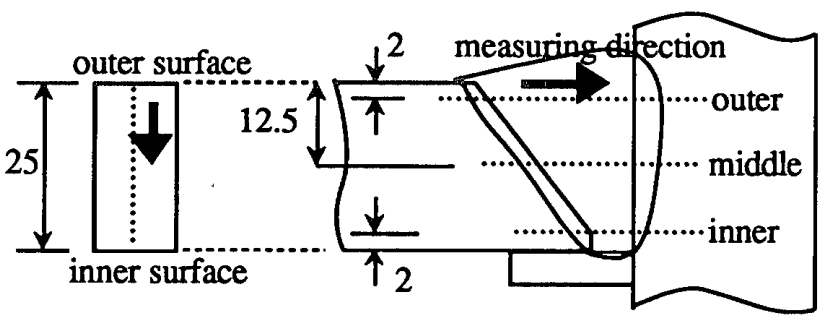

(1) 試験体 A, B

(2) 試験体C, D

Fig. 7 ビッカース硬さ測定位置

すものであり，一様伸びを測定するために文献 13）の 方法にならって材軸方向に $1 \mathrm{~mm}$ ピッチでビッカース打 痕（標点）を付けた。大ひずみ域ではひずみゲージの不 調によってひずみの测定が不能になることがあるが，そ の場合でもこのような細かいピッチの標点をあらかじめ 付けておくことにより残留伸びの分布を測定することが でき，非破断部の残留伸びから一様伸びを知ることがで きる。さらに，この標点を頼りに破断位置が溶接継手の どの位置で起こったかを特定することができる。衝撃試 験片はVノッチシャルピー衝撃試験片（JIS-4 号）であ り，ノッチ先端がプレス曲げ試験体の表面から $3 \mathrm{~mm}$ と なるように採取した。

冷間加工を受けた鎆材の機械的性質はひずみ時効の影 響を受け, 加工後の時間の経過とともに強度の上昇, 延 性伸びと衝撃值の低下が進行し，あるところで収束する ことが知られている。本研究では，試験体に時効処理は 行わなかったが, 加工後約 2 力月経過した時点で載荷実 験を行ったので，おおむね時効は終了していたと考えて よい。念のため，試験片間における時効の差を排除する ため，試験体の製作と実験はすべての試験片に対しそれ ぞれ同じ時期に行った。

\section{3. 実験結果と考察}

\section{1 硬さ試験結果}

硬さの测定値をFig. 7-(1)，(2) に示す。試験体Aと $\mathrm{B}$ については，角部と平板部から切り出したマクロ試験 片を用いて板厚方向のビッカース硬さを試験荷重 $10 \mathrm{kgf}$ で調べた。その結果を Fig. 8-(1)に示す。これによると, プレス加工のままの試験体の平板部 A 2 と熱処理試験体 の角部B1 および平板部 B2 の硬さは板厚方向に関して ほぼ均一であり， 3 者とも 150 前後の值を示している。 これは，引張強さに換算するとおおむね $5.0 \mathrm{t} / \mathrm{cm}^{2}$ に相 


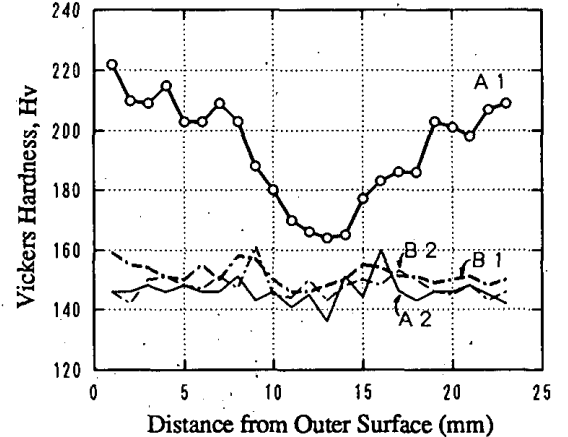

（1）試験体A，Bの角部执よび平板部

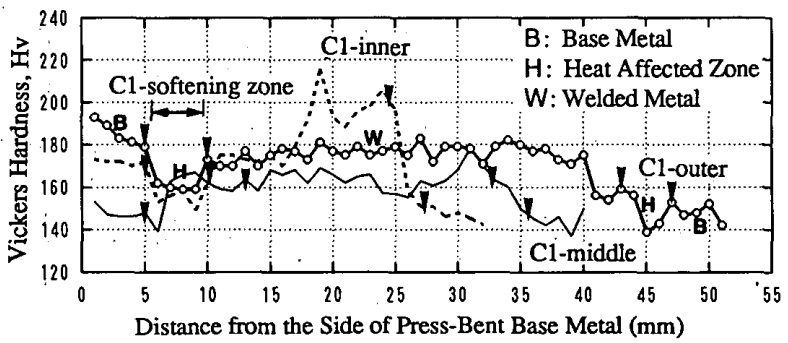

(2) 試験体のの角部

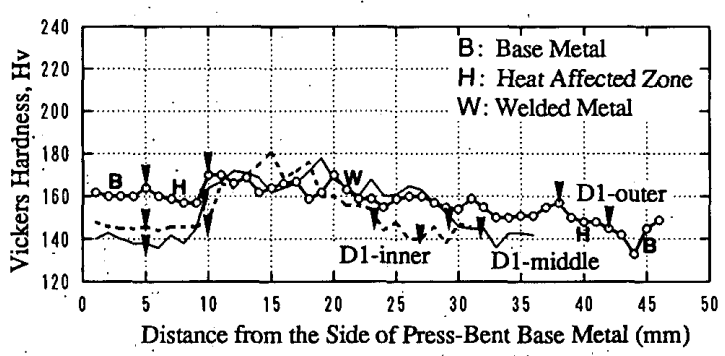

(3) 試験体Dの角部

Fig. 8 ビッカース硬さ分布

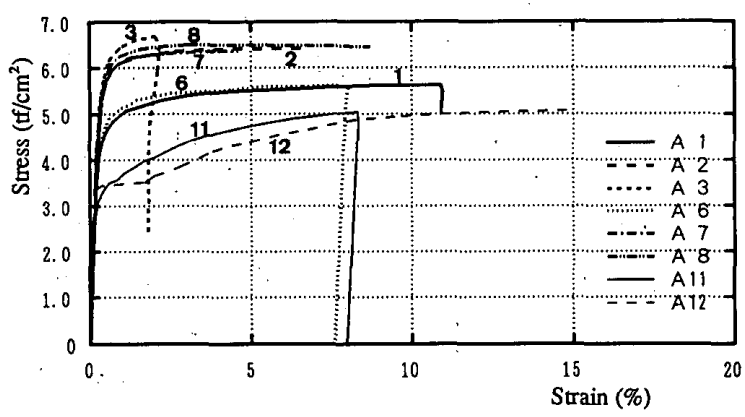

（1）試験体 A

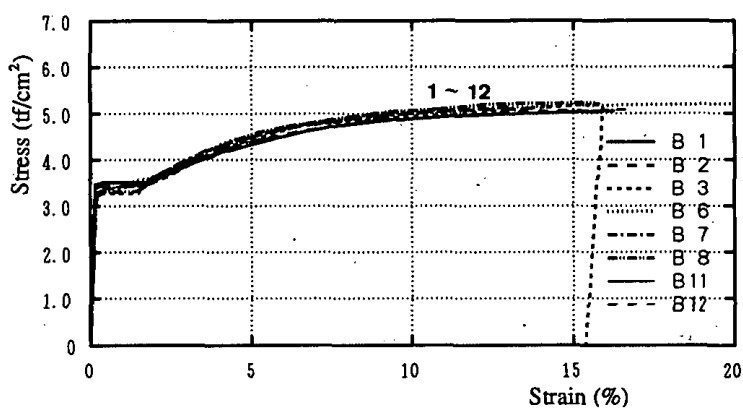

(2) 試験体 B
当する。ところが，プレス加工のままの試験体の角部 A 1 については板厚中央から外表面および内表面に向 かって硬さが急激に高くなっでおり, 表面近傍では硬さ が 210 前後となっており, これを引張強さに換算すると $7.0 \mathrm{t} / \mathrm{cm}^{2}$ 前後に達していると推定され，これは後述の 小形引張試験結果とほぼ一致している。A1において, 板厚中央もやや硬化しており，また外表面のほうが内表 面より硬くなっていることから，プレス曲げによって角 部全体に若干の引張ひずみが導入されると考えられる。

試験体 CとDについては，Fig.7-(2) に示すように 溶接部を含んで外側表面から $2 \mathrm{~mm}$, 板厚中央, 内側表 面から $2 \mathrm{~mm}$ の深さで硬さを調查した。その結果を Fig. 8-(2)，(3) に角部についてのみ示す。同図にはミ クロ組織観察に基づいて母材 (B), 熱影響部 ( $\mathrm{H}$ ), 溶 接金属（W）の各域を印で区切りそれぞれの記号で示 してある。溶接試験体 Cの角部 C1 の外側と内側では, 熱影響部に軟化域が観察される。これは冷間塑性加工で 硬化した材質が溶接熱によって焼きなまされたものであ る。熱処理を施した溶接試験体の角部 D 1 については, 溶接金属部を含めて硬さが均一化する傾向が見られる。

\section{2 小形引張試験結果}

小形引張試験から得られた応力一ひずみ線図を試験体 A，B，C，DごとにFig.9-(1)，(2)，(3)，(4) に示す。 本研究における応力とひずみはすべて公称応力と公称ひ ずみである。ひずみは塑性ひずみゲージによる測定值で あるが, 除荷カーブの無い応力-ひずみ線図はひずみゲー ジの不調によって最大荷重までのひずみが測定できな かったものである。同図より，プレス曲げのままの試験

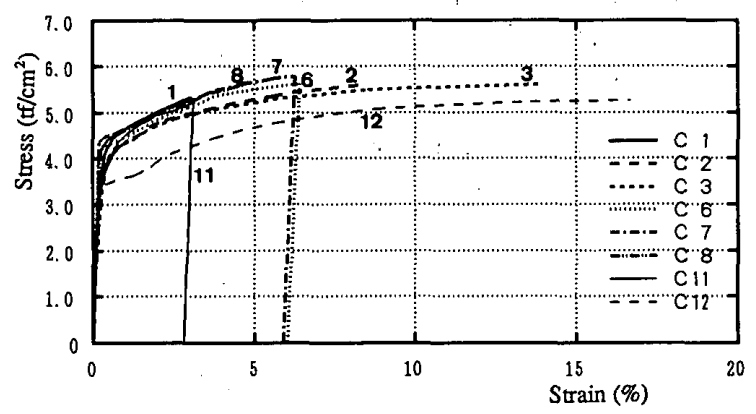

(3) 試験体 C

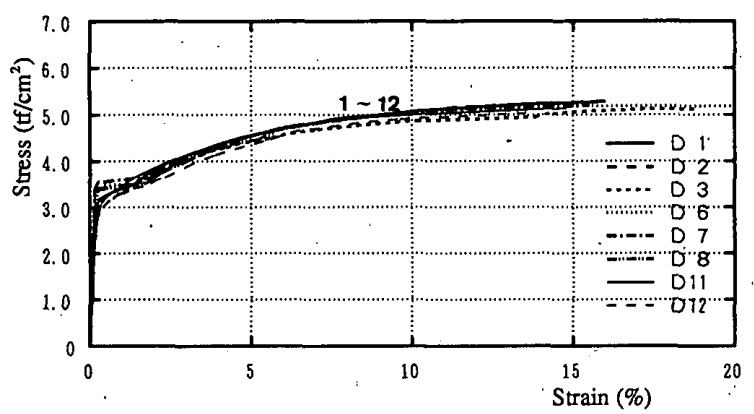

（4）試験体 D

Fig. 9 小形引張試験による応力ーひずみ線図 


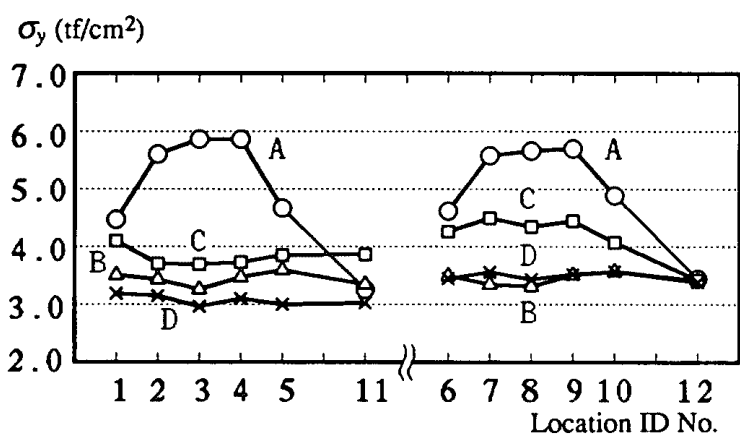

(1) 降伏強さ $\sigma_{y}$ の断面内分布

$\sigma_{u}\left(\mathrm{t} / \mathrm{cm}^{2}\right)$

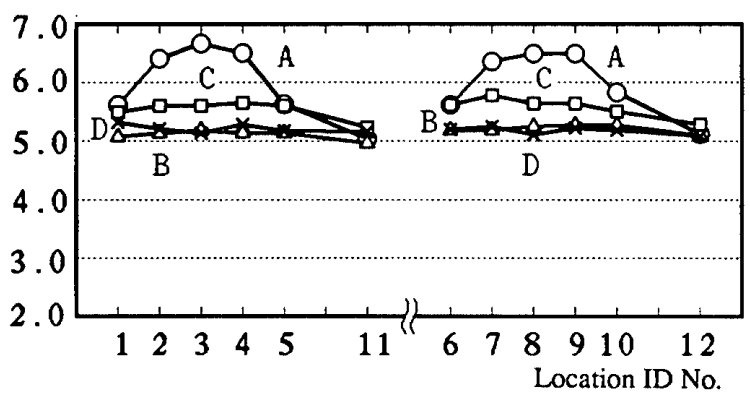

(2) 引張強さ $\sigma_{u}$ の断面内分布 $\varepsilon_{u}(\%)$

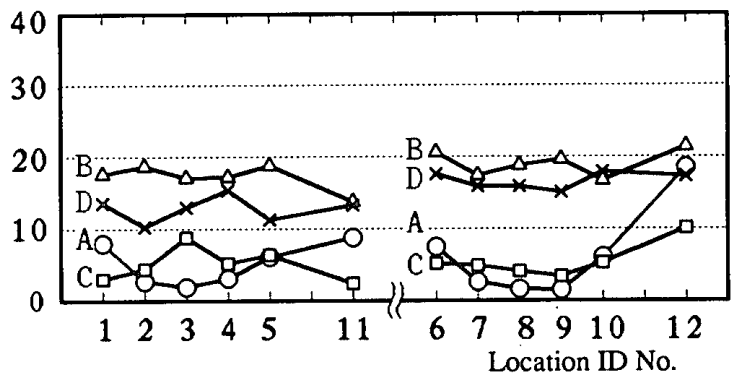

(3) 一様伸び $\varepsilon_{u}$ の断面内分布

$\varepsilon_{b}(\%)$

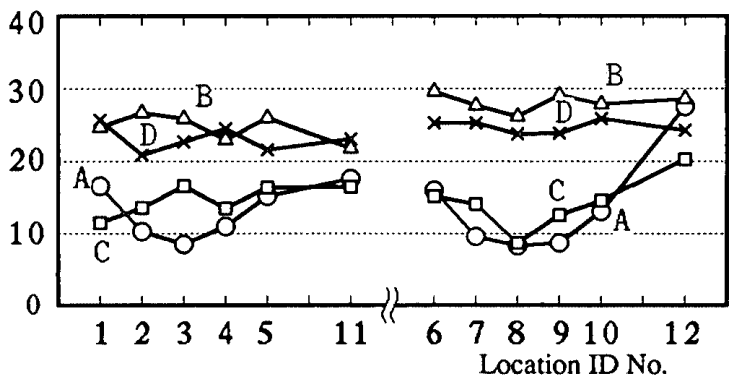

(4) 破断伸び $\varepsilon_{b}$ の断面内分布 $(\mathrm{GL}=40 \mathrm{~mm})$

Fig. 10 引張試験から得られた各種特性值の断面内分布

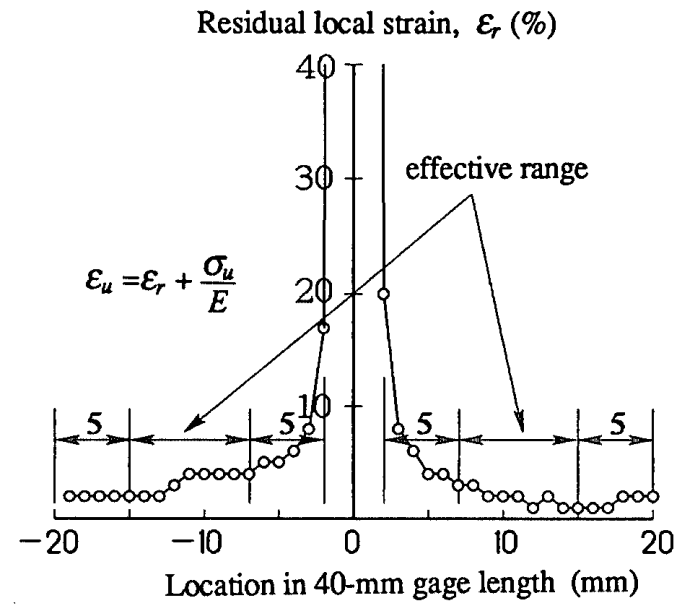

Fig. 11 一様伸び $\varepsilon_{u}$ の測定方法

体 $\mathrm{A}$ では，角部内の位置によってカーブが著しく異なっ ていることがわかる。これは，冷間プレス曲げによって 受ける予ひずみ量が角部内の位置によって異なるためで ある。溶接試験体 Cでは，溶接熱によって材質がなまさ れることにより，Aに比べてカーブが集約される傾向が 見られる。熱処理を施した試験体 $\mathrm{B} ， \mathrm{D}$ は応力ーひずみ 特性が均一化し，しかも原板の状態に復帰している様子 が見られる。

降伏強さ, 引張強さ，一様伸び，破断伸びの断面内に おける分布をそれぞれ Fig. 10-(1)，(2)，(3)，(4) に示 す。ここで，降伏強さは $0.2 \%$ オフセット耐力である。 一様伸びは Fig. 11 に示すように小形引張試験片にあら かじめ付けておいた $1 \mathrm{~mm}$ ピッチの標点間を試験後に顕 微鏡測定すること（測定精度 $1 / 100 \mathrm{~mm}$ ) によって求め

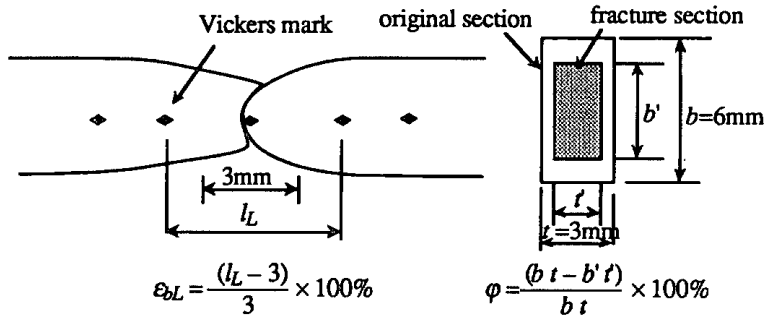

Fig.12 破断位置における局部伸びと絞りの測定方法

た残留局部伸びを基に計算したものである。このとき， 破断縁から $5 \mathrm{~mm}$ および両端標点から $5 \mathrm{~mm}$ の範囲は除 いた。Fig.10の中で最も際だった特徵は，プレス曲げ

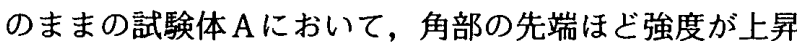
する反面, 伸び能力が減少している点であり，これは外 側 (引張予ひずみ側) と内側（圧縮予ひずみ側）でおお むね対称である。これに対して，熱処理を施した試験体 Bでは，角部全体が均質化し，強度，伸び能力ともに原 板の状態に復帰している。溶接試験体 Cでは，冷間プレ ス曲げによって硬化した部分が溶接熱によって軟化する ので母材試験体 Aに比べて強さは低下するが，伸びは若 干上昇する傾向が見られる。なお，Cシリーズの小形引 張試験片は，小さなブローホールのためデポ破断した $\mathrm{C} 8$ と母材破断した C 12 を除きすべて熱影響部で破断し た。これは,Fig.8-(2) から分かるように熱影響部の 軟化域の長さが約 $4 \mathrm{~mm}$ であり, 小形引張試験片の板厚 $3 \mathrm{~mm}$ より大きいので強度が軟化部の影響を受けたため である ${ }^{14)}$ 。熱処理を施した溶接試験体 Dでは，試験片の 平行部に含まれる溶接金属・熱影響部・母材の均質化が 
$\varepsilon_{b L}(\%)$

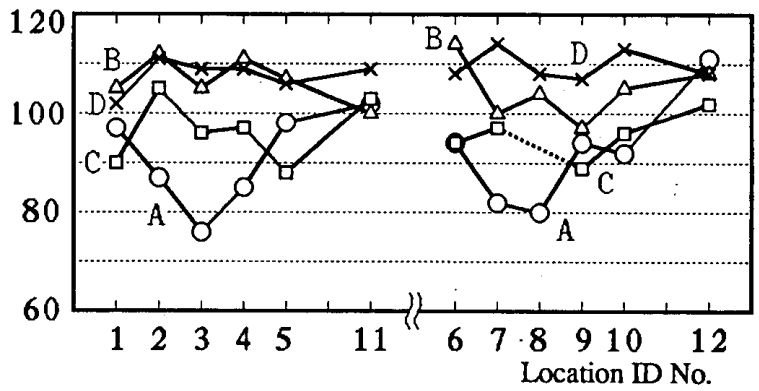

（1）局部伸び $\varepsilon_{b L}$ の断面内分布 (GL=3mm)

$\varphi(\%)$

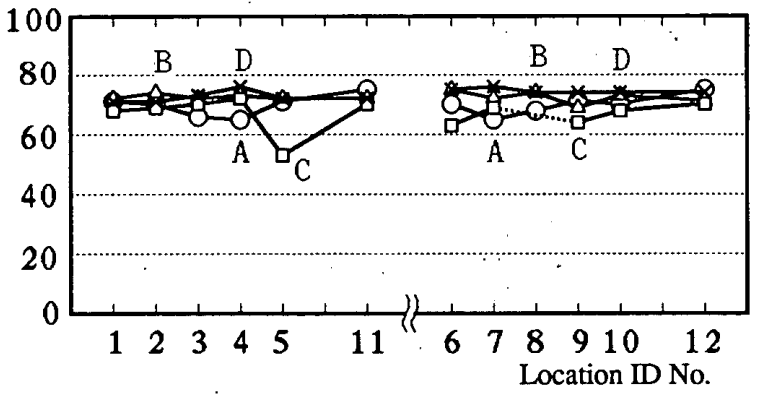

(2) 絞り $\varphi$ の断面内分布

Fig. 13 破断部の局部伸びと絞りの断面内分布

進行するので, 試験体 Bとほぼ同じ引張試験結果が得ら れた。

破断部の局部的な変形状態を比較するために, Fig. 12 に示すように破断位置をほぼ中央に含んだ標点 間 $3 \mathrm{~mm}$ における局部破断伸び $\varepsilon_{b L}$ と破断面の絞り $\varphi$ を 調べた。その結果をFig. 13-(1)，(2) に示す。これら の破断部における局部的な変形能力は $\mathrm{A}<\mathrm{C}<\mathrm{B} \approx \mathrm{D}$ の 順になっているが，その差は一様伸びに比べると顕著で はない。部材接合部の延性亀裂の発生・進行に対して, 鋼材の一様伸びと局部伸びのどちらが有効な指標になる かは明らかではないが，延性龟裂から発生する脆性破壊 がほとんど断面収縮を伴わないことを考えると一様伸び のほうが重要であろうと推測される。

角部先端の外側（位置 3）から採取した小形引張試験 片の実験後の様子をFig. 14 に示す。A 3 と B 3 を比較 すると，破断伸びに大きな違いが見られる。

\section{3 シャルピー衝撃試験結果}

$0^{\circ} \mathrm{C}$ におけるシャルピー衝撃試験から得られたシャル ピー吸収エネルギーの断面内分布をFig. 15 に示す。こ れにより，プレス曲げのままの試験体 Aでは，外側（引 張予ひずみ側）で角部先端ほど衝撃值が急激に低下する ことがわかる。特に，角部先端 A 3 の吸収エネルギーは わずか $2.0 \mathrm{kgf} \cdot \mathrm{m}$ であり，平板部の $1 / 12$ にまで低下し ている。しかし，内側（圧縮予ひずみ側）では衝撃值は 低下していない。これは，単純圧縮によって予ひずみを 与えた場合にも単純引張りによって予ひずみを与えた場 合之同様に衝撃値が低下するという従来の実験結果 ${ }^{15)}$ と 異なっているが，その原因は明らかではない。

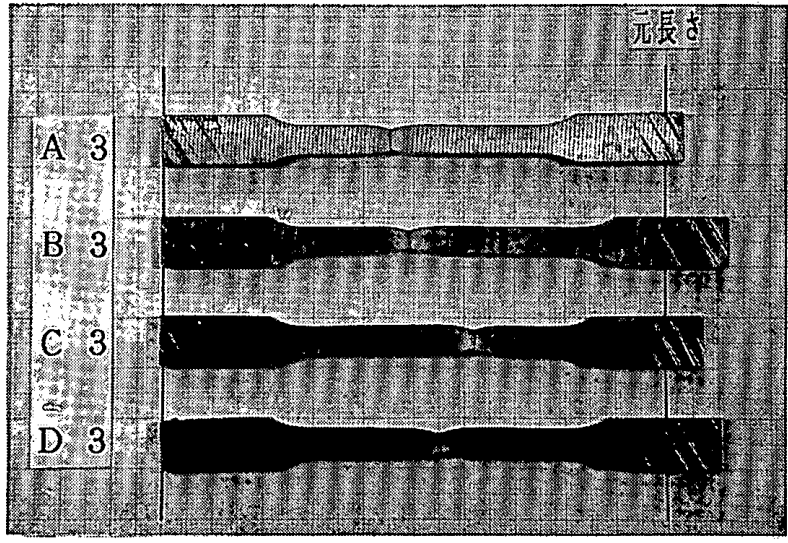

Fig. 14 破断後の小形引張試験片（採取位置：角部先端外側）

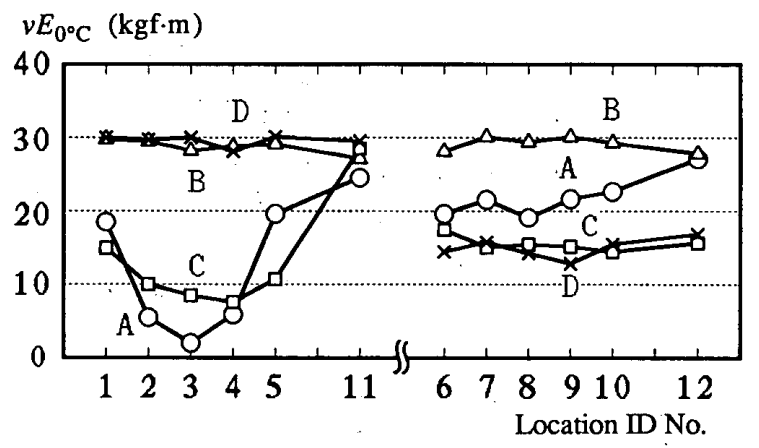

Fig. $150^{\circ} \mathrm{C}$ シャルピー吸収エネルギーの断面内分布

熱処理を施した試験体 B では角部全体が均質化し， シャルピー吸収エネルギーはほぼ一定であり，しかもそ の值は熱処理前の平板部より高い值を示している。これ は, 熱処理によって結晶の細粒化が進行したためである。 溶接試験体 Cの外側では，溶接熱によって冷間加工によ るひずみ脆化部の靶性が若干回復するので, 衝撃值が試

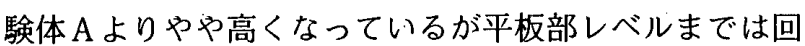
復していない。試験体Cの内側の值は溶接金属の衝撃値 となるので採取位置によらず值はほぼ一定で，母材平板 部より值が低い。熱処理を施した溶接試験体 Dの外側は, 靱性が完全に回復し, B と同じ高い衝撃値を示している。 ただし，内側は溶接金属の衝撃値となるので熱処理の効 果は現われず，Cと同じである。

外側の平板部（位置 11）と角部（位置 $1,2,3$ ）から 採取した衝撃試験片の試験後の破面を全試験体 A，B， C，Dについて Fig.16に示す。この中で最も顥著な現 象は，試験体 Aで角部の先端に向かうほど脆性破面が支 配的となることである。特に，角部先端（位置 3）の衝 擊試験片 A 3 の破面はほぼ全断面が脆性破面で断面に全 く絞りが生じていない。もう少し細かく観察すると, A 3 以外の試験片では，Vノッ千底付近に延性破面が見 られ，延性亀裂が進行してから脆性破面に移行している 様子が観察されるのに対して，A3ではVノッチ底付近 にもほとんど延性破面が見られず，極めて小さな延性亀 裂が引き金となって脆性破壊が起こりうることを示唆し ている。溶接試験体の角部先端 C 3 では，溶接熱影響に 


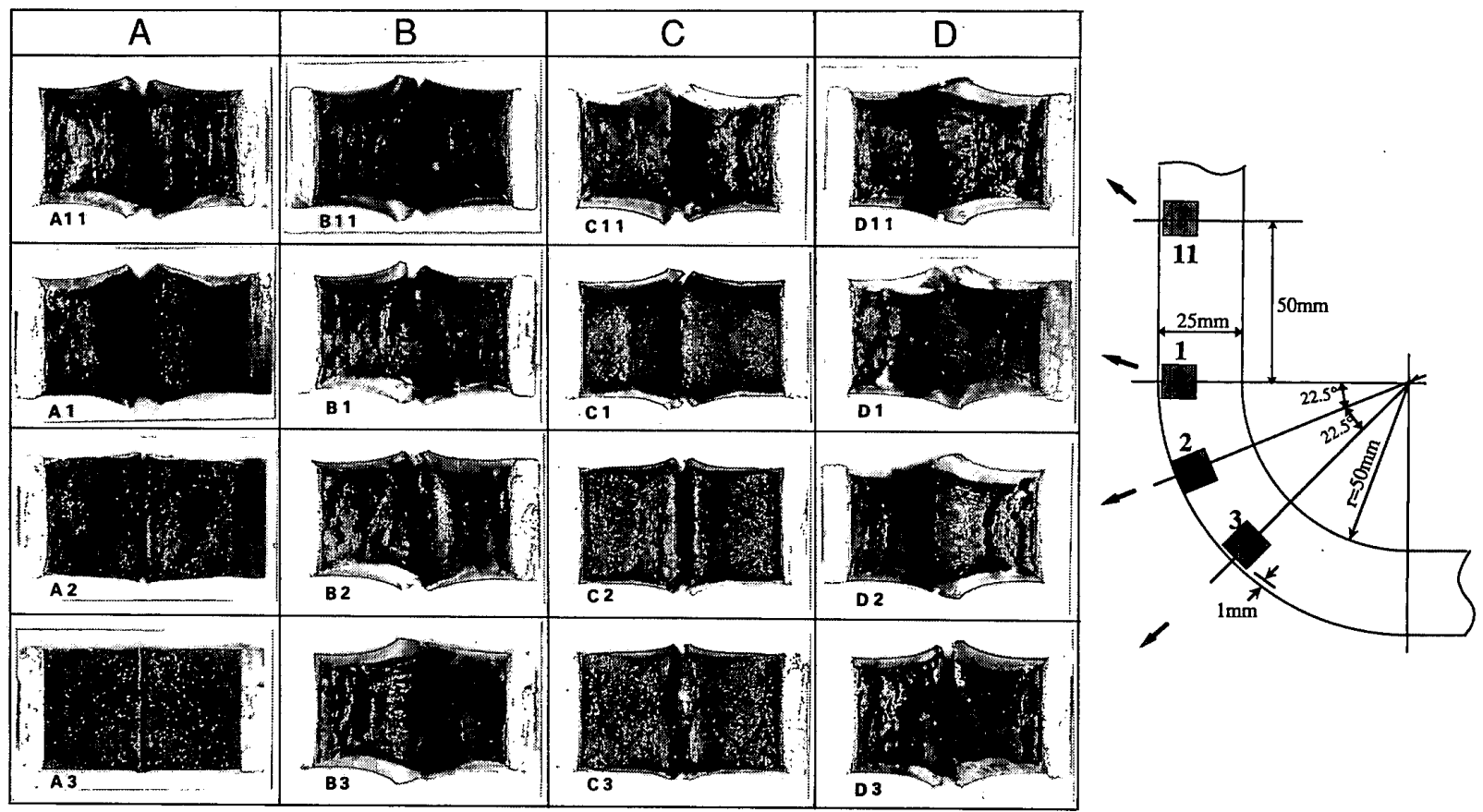

Fig.16 衞擊試験片の破面（試験温度 $0^{\circ} \mathrm{C}$ )

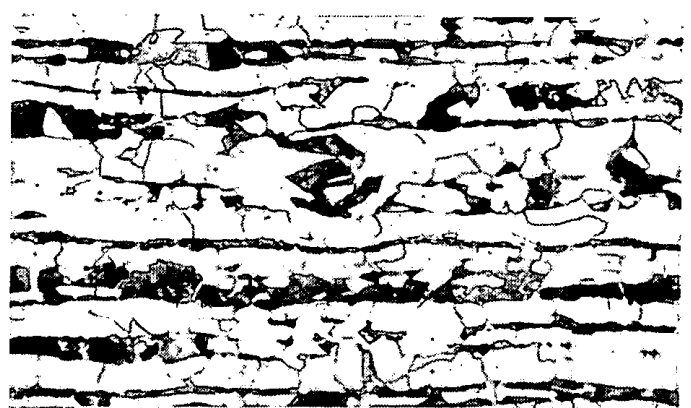

（1）試験体 A

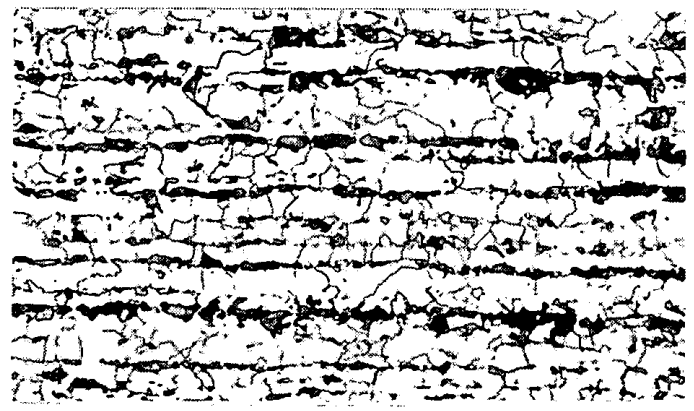

（2）式験体 B

Fig. 17 ミク口組織 $\times 200$

(観察位置：角部外側表面から深さ $2 \mathrm{~mm}$ )

よって予ひずみ脆化部の勒性がやや回復するため，ノッ 于底に延性破面が認められる。熱処理を施した試験体 B およびDの角部先端における衝撃試験片 B 3，D3 ではほ ぼ全断面延性破面で断面に十分な絞りが生じている。

\section{4 ミクロ観察結果}

試験体 A，Bの角部の外側表面から $2 \mathrm{~mm}$ の深さにお けるミク口組織を Fig. 17-(1)，(2）に示す。いずれも フェライト (白い部分) のパーライト（黒い部分）が縞
状をなしているが，Bでは熱処理によって結晶粒が微細 化している様子がわかる。

\section{4. 結 論}

SM 490 鋼板を冷間プレス曲げ加工した武験体および それに熱処理 $\left(850^{\circ} \mathrm{C}, 30\right.$ 分）を施した試験体から引張 試験片やシャルピー衝撃試験片などを切出し，材質を調 查した。プレス曲げのままの試験体については，外側角 部（引張予ひずみ側）で延性伸びおよび切欠き勒性が平 板部より著しく低下することが判明した。これに対して， 熱処理を施したものは，延性伸びおよび切欠き勒性とも に完全に回復し，原板よりもむしろ高い値を示した。

このプレス曲げ試験体を柱貫通ダイアフラムに相当す る鋼板に突合せ溶接し，溶接のままのものと溶接後熱処 理 $\left(850^{\circ} \mathrm{C}, 30\right.$ 分) を施したものについて，溶接部近傍 の材質を調查した。溶接入熱によって，冷間加工による 硬化部が部分的に軟化し，伸び能力と衝撃値が若干回復 する傾向が見られたが，原板レベルまでは復帰しなかっ た。ただし，溶接後熱処理を施したものは，材質が完全 に回復し, 冷間加工前の母材レベルまたはそれ以上の伸 び能力と衝撃値を発揮した。

以上の実験結果により，冷間プレス成形コラムで今ま で観察されている角部外側からの高応力脆性破壊の原因 は, 角部の延性伸び能力の不足に起因して溶接止端応力 集中部から早期に延性亀裂が発生進行し，さらに切欠き 靶性の不足に起因してその延性亀裂か脆性破壊に容易に 転化するものと推定される。しかしながら，本研究で調 查した伸び能力や衝撃値が高応力脆性破壊の発生・伝播 の条件とどのような定量的な関係があるかについては依 
然不明であり, 板厚, 溶接入熱, 初期欠陥などの他の要 因も含めて今後解明しなければならない研究課題であ る。また，今回材質改善策として試みた熱処理はかなり 高温での熱処理（焼きならし処理）で，完全な材質改善 を狙ったものであるが，より低温域での熱処理によって も必要最小限の材質改善は達成できるかも知れない。

このような高応力脆性破壊の可能性を有するプレスコ ラムの安全性は, 柱部材にどの程度の塑性変形能力を期 待する設計を行うかにかかわっており，これについては 構造物全体の崩壊機構と関連付けながら検討していく必 要がある ${ }^{16)}$ 。

\section{謝 辞}

本研究を行うに当たって, 文部省科学研究費一般研究 （A） 04402041 (研究課題名：破壊現象を伴う鋼構造部 材の塑性変形能力に関する研究,研究代表者: 桑村 仁) の補助を受けた。

\section{参考文献}

1) 桑村 仁, 秋山宏, 山田哲, 邱 榮政: 冷間プレス 成形コラムの材質とその改善に関する模擬実験, 日本建 築学会大会学術講演梗概集, pp. 1287～1288, 1992.8

2) Osborn, C. J., Scotchbrook, A. F., Stout, R. D., and Johnston, B.G. : Effect of Plastic Strain and Heat Treatment, The Welding Journal, AWS, pp. 337 -353, 1949.8

3) Osborn, C. J. : The Nature of Strain-age Embrittlement, Journal of ISI, pp. 97 101, 1958. 2

4）藤本盛久, 守谷一彦, 和田 章：塑性履歴をうけた鋼材 ならびに部材の力学的性状に関する研究, 日本建築学会 論文報告集，第 167 号，pp. 13～24，1970.1

5）青木博文, 中込忠男, 増田正之: 塑性歪を受けた構造用 鋼板の力学的特性に関する研究，日本建築学会大会学術 講演梗概集, pp. 1491 1492，1984. 10
6) 中込忠男, 青木博文 : 塑性雨を受けた構造用鋼材の力学 的性能に関する実験的研究, 構造工学論文集, Vol. 38 B, pp. $369 \sim 376,1992.3$

7）日本道路協会：道路橋示方書 - 同解説, pp. 344 - 347, 1973. 12

8）堀川浩甫：冷間塑性加工に伴う構造用鋼材のひずみ時効 脆化, 土木学会論文報告集, 第 300 号, pp. 13 20, 1980.8

9）日本鋼構造協会：日本鋼構造協会規格 JSS II 10-1988, 冷間成形角形鋼管 (ボックスコラム), pp. 1 23, 1988

10）秋山宏, 桑村 仁, 山田哲, 邱榮政, 菊川春三: 角形鋼管の終局挙動に及ぼす製造工程の影響, 構造工学 論文集, Vol. 38 B，pp. 399 410，1992.3

11）中村秀夫：プレス成形コラムの柱部材としての性能, 鉄 構技術，（上）pp. $51 ５ 7 ， 1990.11$ ，(下）pp. 52 57， 1990.12

12）鈴木健二, 高田信宏ほか：プレス成形角形䤡管柱の性能 評価, 日本建築学会大会学術講演梗概集, (その 1 ) pp. $1481 \sim 1482$ ， 1990.10, (その 2) pp. 1483 1484, 1990.10, (その3) pp.1309 1310, 1991.9, (その4) pp. 1311 1312, 1991.9

13）桑村 仁，前田孝一：低 YR 高張力鋼の機械的性質に及 ぼす歪速度の影䭒, 構造工学論文集, Vol. 36 B, pp. 385 $\sim 397,1990.3$

14）桑村 仁，岡村義弘，村岡寛英：低 YR 70 キ口高張力鋼 の溶接継手強度について, 構造工学論文集, Vol. 34 B, pp. $141 \sim 149,1988.3$

15）吉識雅夫：切欠脆性の工業的試験法の研究, 第 10 章 構 造用鋼の霆時効に関する研究, 日本造船研究協会報告, 第 14 号, pp. 47 53, 1957.3

16）桑村 仁：崩壊機構に基づいた鋼構造建築物の耐震設計, 日本建築学会関東支部構造部会シンポジウム, 鉄骨造に おける崩壊モードと耐震安全性, pp. 15２3，1992.2

(1992 年 7 月 10 日原稿受理, 1992 年 11 月 12 日採用决定) 